\title{
Teaching Spoken English at Junior High School: A Comparison of TPR and PPP
}

\section{Christian Jones}

University of Central Lancashire

Michelle Lees

Oita JET Programme

Natalie Donohue

\section{Bilkent University}

Karen Smith

University of Central Lancashire

This article reports on an experimental methods-comparison study, which was undertaken with beginner level junior high school students (aged 12 and 13) in Japan. The study aimed to investigate which type of teaching, Total Physical Response (TPR) or Present Practice Produce (PPP), was more effective in developing productive and receptive knowledge of a set of collocations. Results showed that both types of teaching had a significant impact upon the development of understanding and using the target language. However, there were no significant differences between the effectiveness of TPR and PPP apart from a short-term benefit for PPP in terms of receptive knowledge. This shows that both types of teaching can have a positive impact upon learners of this age and level and that there is a need for further research to investigate the effectiveness of these communicative methodologies in this context.

本論は日本における初級レベルの中学生 (12～13歳)を対象とした実 験方法・比較研究を紹介したものである。本研究では、一連の連語の生 産的・受容的知識を習得するために、Total Physical Response (TP一身 体の動きを通して「聞くことの」の能力を発達させる方法)と、Present Practice Produce (PPP一教師が提示、学習者が練習・産出)のどちらの教 授法がより効果的かを調査した。この2つの教授法は学習者の目標言語 英語) の理解や使用に重要な影響を与えるという結果がでた。しかし、 受容知識におけるPPPの短期間の利点を除けば、両教授法に有意差はな かつた。したがつて、この2つの教授法はこの年齢と学習レベルの学習者 には肯定的な効果をもたらすことを示しているので、これらのコミュ二ケ 一ション教授法の効果を調査するさらなる研究が必要になるであろう。

$\mathrm{n}$ recent years the Japanese governmental body, Japan's Ministry of Education, Culture, Sports, Science and Technology (MEXT), has dictated reforms to its teachers in the hopes of ousting the long-standing traditional grammar-translation method and improving the communicative competence of pupils. However, it is well-known that the implementation of these reforms at a classroom level is often difficult (e.g., Glasgow, 2012). Obstacles include the aforementioned established grammar translation, the focus on high-stake entrance exams which do not test pupils' communicative abilities, and practical problems such as how Japanese teachers and Assistant Language Teachers (ALTs) can best work together to implement these reforms. In addition, although there has been no shortage of opinion about the shortcomings of English language education in Japan and what the solutions are, there is a need for experimental studies or classroom research in general in order to offer teachers evidence-based models for successful communicative language teaching, which they can implement with confidence. This article aims to compare Total Physical Response (TPR) and Present Practice Produce (PPP) as two practical, classroom-based methods of achieving greater communicative competence with first-year junior high school pupils (aged 12-13 years old). Although the study is situated in a specific context, it is also felt that the results could be applicable to any situation where there is a desire to teach young learners English more communicatively, without recourse to grammar translation. We recognise that this is a method which has some clear benefits (Cook, 2010), but we feel it is less effective in helping young learners to speak English. In this study, TPR and PPP were compared to assess to what extent either were effective in aiding learners to understand and use a set of target collocations communicatively.

The two research questions considered in this study are as follows:

- RQ1: To what extent was either of the treatments (PPP or TPR) more effective than the other in terms of aiding learners to recognise the target collocations?

- RQ2: To what extent was either of the treatments (PPP or TPR) more effective than the other in terms of aiding learners to produce the target collocations?

Our hypotheses were that TPR should be more effective in fostering receptive knowledge, while PPP 
would be more effective in developing the ability to produce the target collocations. If correct, we felt it would be possible to advocate the use of TPR in initial stages of learning and then for teachers and ALTs to use PPP to help learners gain confidence in producing language, as a model of a weak form of Communicative Language Teaching (CLT), where there is a clear emphasis on form.

\section{TPR and PPP}

This study examines two alternative ways of introducing and teaching spoken language, which we would hope teachers of English in Japan could use within their own classrooms.

Total Physical Response (TPR) was developed by Asher (1969) and is based on the suggestion that achieving proficiency in all four skills in foreign languages with limited teaching is overambitious. TPR works on the premise that if listening ability alone is intensely focussed on, the other skills will also improve, particularly with learners of low level proficiency. Asher believes language production will develop from comprehension (Asher, 1969) and therefore learners will speak when they are ready to speak. TPR aims to stimulate learning through physical movement. The basic principle is that the $\mathrm{L} 2$ is taught by giving commands that require the learner to physically move to complete. Asher (1969) also recommends that the $\mathrm{L} 2$ should be the sole medium of instruction.

PPP (Byrne, 1986) is generally considered as a way to teach language within a weak form of Communicative Language Teaching (CLT), where a form or forms are given a clear context and practised via communicative activities. Weaker forms of CLT take a "learn to communicate" approach and allow for explicit instruction of language and pre-communicative practice such as drilling, unlike the strong form where there is a "communicate to learn" approach with no explicit form focus. A lesson using PPP initially involves the presentation (showing language in context) and explicit explanation of new vocabulary or grammar, before learners practise the target language through drills and other controlled practice activities. Finally, the learners produce the language in order to develop fluency and confidence (Richards, 2006).

There are several studies that have produced evidence with regard to the effectiveness of TPR in a number of second languages and with a variety of learners (see Asher, 2009, for an overview of the research evidence). In a Japanese context, Watanabe and Kawabuchi (2008) assessed the effect that TPR had on long-term retention of 100 imperative sentences with Japanese first-year junior high school pupils. Compared with a control group taught using a listen-repeat technique, the TPR group showed a significant increase in retention, both in the immediate and delayed post-tests. Additionally, they found that lower-ability pupils achieved higher retention in delayed post-test than higher-ability pupils. Therefore, Watanabe and Kawabuchi (2008) argue that using TPR can be effective in Japanese education, where there is limited teaching time.

PPP has often come under attack in a Western ELT context (see, for example, Lewis, 1993) as being an out-dated, behaviourist methodology, without a basis in second language acquisition theory. This is a rather exaggerated view as PPP has been found to be an effective form of explicit instruction. Yan-Ping (1991, p. 263), for instance, found that teaching Chinese learners grammatical forms through a PPP framework did have a positive effect on their acquisition of those forms, either through an explicit or an implicit statement of rules, leading her to suggest "form-based classroom instruction is conducive to the success of SLA, be it implicit or explicit." In a study investigating learners of Japanese, Yoshimi (2001) also produced evidence that presentation and explicit explanation of discourse markers, followed by practice and corrective feedback, helped learners to use them within informal spoken narratives to a much greater extent than a control group given no explicit focus of the same items. More recently, Muranoi (2007, p. 76) has reviewed a number of studies investigating the effect of output practice and concludes that "results of empirical studies on the effects of output practice, especially those conducted in classroom situations, generally indicate that providing learners with opportunities for producing output in language use contexts is facilitative in developing learners' interlanguage."

Despite this evidence, relatively few studies have tested these ways of teaching in a Japanese context and, in particular, in the first stages of junior high school. In addition, many methods-comparison studies take a grammatical form as the main linguistic focus. This study aims to address these gaps by offering an evidence-based model for teaching lexis communicatively in the Japanese context that could be applied by teachers in class or may stimulate teachers' own action research. TPR and PPP were chosen because we felt that they could be effective with learners at this age and at a beginner level. TPR is a way of teaching which could remove the pressure on learners not yet ready to speak and be an enjoyable way to learn. PPP is a way of teaching that could take learners through some new language step by step, building their confidence to use it productively. 


\section{Method \\ Participants}

The participants were drawn from two intact classes in Oita prefecture in Japan and all pupils were at false beginner level, having received only initial English language tuition at elementary school, which provides pupils with a basic working vocabulary. Both classes were taught by one of the researchers as part of the JET programme. The initial sample size was 50 but due to some pupils missing one of the three tests, this was reduced to a final sample of 45: 22 in the TPR group and 23 in the PPP group. The mean age was 13 and there were 27 male and 23 female participants.

\section{Study Design}

The study followed an experimental design of pretest, treatment, post-test, and delayed test. The language focus was on collocations related to cooking, such as "steam the rice." These were chosen because we felt the collocations were appropriate for the level of proficiency of the learners, useful, and possible to teach using either TPR or PPP. Pupils were first given a productive and receptive pre-test (see Appendix A) prior to teaching the class. Following this they were each taught the same language using either TPR or PPP (see Appendix B for more details of lesson procedures) for the duration of one forty-minute class. We differentiated between the ways of teaching in the following manner: The lessons were staged similarly but in order to emphasise the receptive focus of TPR we have described above, TPR learners were not required to speak but had to show understanding of the target language through a series of comprehension activities, including the use of gesture and mime and sequencing activities. The PPP learners were presented with the collocations and then practised the language in both controlled and free activities, such as drilling and role-plays. Each class was followed by an immediate productive and receptive test (see Appendix A), which was also repeated after a delay of two weeks, with the order of questions altered to prevent pupils memorising the answers. There was no further instruction on the target items between the class and the delayed test. The results were analysed by looking at the gains made in each test by each group at each stage (from pre-post-test, from post-delayed test and from pre-delayed test), as it is considered that this can be attributed to the effect of the experimental teaching (Schmitt, 2010). The scores were calculated and then analysed for statistical significance using an independent samples t-test to compare the gains made by each group and a paired samples t-test to calculate the effect within each individual group.

\section{Results and Discussion}

RQ1: To what extent was either of the treatments (PPP or TPR) more effective than the other in terms of aiding learners to recognise the target collocations?

The scores at the pre-test stage were low for both groups when assessing their receptive awareness of the targeted language $(M=1.7391$ out of a maximum score of nine for the TPR group and $M=1.2273$ out of a maximum score of nine for the PPP group), although, as we would expect, it was superior to their productive knowledge of the target items. The teaching had a clear impact on the receptive awareness of both groups, apart from the gains made from post- to delayed tests, as we can see in Tables 1 and 2 below. Table 1 shows the descriptive statistics for each group and Table 2 the gain scores, significance, and effect sizes, using Pearson's correlation (r), as described in Field (2013). The measures of small, medium, and large effect sizes are taken from Cohen (1988).

Table 1. Receptive Test Results

\begin{tabular}{llll}
\hline Group & \multicolumn{1}{c}{$\begin{array}{c}\text { Pre-test } \\
\text { scores }\end{array}$} & $\begin{array}{c}\text { Post-test } \\
\text { scores }\end{array}$ & $\begin{array}{c}\text { Delayed test } \\
\text { scores }\end{array}$ \\
\hline TPR & $M=1.7391$ & $M=4.1304$ & $M=4.000$ \\
& $S D=2.00493$ & $S D=3.24806$ & $S D=3.10425$ \\
\hline PPP & $M=1.2273$ & $M=5.6818$ & $M=4.9091$ \\
& $S D=1.65944$ & $S D=2.35809$ & $S D=2.79300$ \\
\hline
\end{tabular}

Table 2. Receptive Test Gain Scores

\begin{tabular}{llll}
\hline Group & $\begin{array}{c}\text { Pre-post- } \\
\text { test gains } \\
\text { in receptive } \\
\text { knowledge }\end{array}$ & $\begin{array}{c}\text { Post- de- } \\
\text { layed test } \\
\text { gains in } \\
\text { receptive } \\
\text { knowledge }\end{array}$ & $\begin{array}{c}\text { Pre- delayed } \\
\text { test gains } \\
\text { in receptive } \\
\text { knowledge }\end{array}$ \\
\hline TPR & $M=2.3913 *$ & $M=-.1304$ & $M=2.2609 *$ \\
& $S D=3.51282$ & $S D=3.87655$ & $S D=3.31960$ \\
& $r=.57$ & $r=.03$ & $r=.57$ \\
\hline PPP & $M=4.4545 * *$ & $\mathrm{M}=-.7727$ & $M=3.6818 * *$ \\
& $S D=2.93951$ & $\mathrm{SD}=3.54471$ & $S D=2.99820$ \\
& $r=.84$ & $r=.21$ & $r=.78$ \\
\hline
\end{tabular}

$*=p<.05, * *=p<.01$

$r=.10$ (small effect), $r=.30$ (medium effect), $r=.50$ (large effect) 
These results show there was some attrition in receptive knowledge from post- to delayed tests and there was little effect at this stage but that at other stages (pre-post and pre-delayed test) both groups' scores improved significantly and the effect size was large.

When receptive gains were compared between groups for statistical significance using an independent samples t-test, the PPP group's score was found to be significantly better than in terms of the pre- to post-test scores $(p=.039)$. This difference was found to have a medium size effect $(r=.31)$, which suggests that PPP had a stronger short term effect upon receptive knowledge than TPR in this case.

RQ 2: To what extent was either of the treatments (PPP or TPR) more effective than the other in terms of aiding learners to produce the target collocations?

Table 3. Productive Test Scores

\begin{tabular}{llll}
\hline Group & $\begin{array}{l}\text { Pre-test } \\
\text { scores }\end{array}$ & $\begin{array}{l}\text { Post-test } \\
\text { scores }\end{array}$ & $\begin{array}{l}\text { Delayed test } \\
\text { scores }\end{array}$ \\
\hline TPR & $M=.0435$ & $M=2.7391$ & $M=8.7836$ \\
& $S D=.20851$ & SD $=3.93374$ & $S D=10.09481$ \\
PPP & $M=.5455$ & $M=3.1818$ & $M=9.1364$ \\
& $S D=.80043$ & $S D=3.48652$ & $S D=8.62055$ \\
\hline
\end{tabular}

Table 4. Productive Test Gain Scores

\begin{tabular}{llll}
\hline Group & $\begin{array}{l}\text { Pre- post- } \\
\text { test gains in } \\
\text { productive } \\
\text { knowledge }\end{array}$ & $\begin{array}{l}\text { Post- delayed } \\
\text { test gains in } \\
\text { productive } \\
\text { knowledge }\end{array}$ & $\begin{array}{l}\text { Pre- delayed } \\
\text { productive } \\
\text { knowledge }\end{array}$ \\
\hline TPR & $M=2.6957 *$ & $M=6.0435 *$ & $M=8.7391^{* *}$ \\
& $S D=3.97074$ & $S D=10.70887$ & $S D=10.14632$ \\
& $r=.57$ & $r=.49$ & $r=.66$ \\
\hline PPP & $M=2.6364 * *$ & $M=5.9545 *$ & $M=8.5909 * *$ \\
& $S D=3.170$ & $S D=8.68758$. & $S D=8.72140$ \\
& $r=.64$ & $r=.57$ & $r=.71$ \\
\hline
\end{tabular}

$*=p<.05, * *=p<.01$

$r=.10$ (small effect), $r=.30$ (medium effect), $r=.50$ (large effect)

The scores at the pre-test stage for both groups were very low $(M=.0435$ out of a maximum score of 27 for the TPR groups and $M=0.5455$ out of a maximum score of 27 for the PPP group), suggesting that for all participants, using the targeted collocations was something they were able to do only in a very limited capacity. As a result, there was a large improvement in the scores for both groups following class input. Table 3 shows the descriptive statistics for each group and Table 4 the gain scores, significance and effect sizes.

As we expected, the teaching clearly had an impact upon both groups and pleasingly, unlike receptive knowledge, this did not deteriorate over time, as the gains increased in the two weeks of delay from post- to delayed test. There was a large effect size shown at all stages, suggesting that the instruction had a stronger effect upon the learners' ability to produce the language. This shows that the class input can have a lasting effect upon the pupils' ability to produce target lexis and may be due to the relative ease of remembering collocations instead of grammatical formulas. Although the raw scores also show, somewhat surprisingly, that there was a slightly higher gain on productive knowledge scores by the TPR group, when the scores were compared, there was no statistically significant difference found between the two groups' scores.

\section{Limitations}

This study could be described as limited because of the small amount of input (one class) but we felt it was equivalent to many short treatments in instructed SLA research. In a review of studies of this type, Norris and Ortega (2000,2001), for example, show that a large number studies of this type had a treatment time of two hours or less and that short term treatments tended to have longer lasting effect upon acquisition. We also felt that a single lesson treatment was something which other teachers and researcher could easily replicate.

The use of a paper test for production was also a limitation because it does not replicate spontaneous spoken performance in real time. While the ideal productive test would use an instrument such as an elicited role-play, this was not possible within the class time we had. Therefore, we decided the test type used was a practical compromise and one which we also felt other teachers in a similar situation could use.

\section{Implications for Teaching}

Contrary to expectations, TPR was not shown to be significantly better at developing receptive knowledge and PPP was not significantly better at developing productive knowledge. Both ways of teaching contributed to the development of understanding and ability to use the target language, with PPP having a significantly better impact upon recep- 
tive knowledge in the short term. This was not an expected result and may have been due to a number of factors, including the relatively small sample size. PPP may have also been more similar to the teaching method used in the classes which the pupils take with their ALT, so the immediate impact was stronger. The results also suggest that both PPP and TPR can be effective as communicative ways to teach and have positive impacts upon understanding and producing language, which can be sustained over time.

As a way of achieving the goals of MEXT, PPP and TPR may be a useful way in for those teachers used to grammar translation. However, PPP may be easier, initially, to actualise in classrooms and less of a jump for teachers than either TPR or task-based learning, which may need extensive syllabus and materials development to assist with implementation. Sato (2010) also suggests that PPP may be suited to Japanese classrooms because in an environment with a scarcity of English input, practice of specific language forms is important.

While we would not wish in any way to suggest PPP is the answer to teaching communicatively in Japan, it would at least be a step forward, particularly with young learners of this age and level. Giving teachers and ALTs frameworks such as PPP to use could assist with this process.

\section{Implications for Further Research}

Given that the results of this study contradicted our own assumptions, it would be useful for others to replicate the study in similar contexts in Japan. If feasible, this could be undertaken with larger sample sizes to try to obtain more definitive results that could be generalised more widely. It would also be helpful, if possible, to amend or supplement the test used with an oral test, such as an elicited role-play. Learners could, for example, be asked to give spoken instructions to a friend about how to cook something.

Useful comparisons could also be made between PPP, TPR, and grammar translation to assess their impact upon receptive and productive knowledge of target language. We hypothesise that the predominant use of L2 in the classroom, which is a feature of both TPR and PPP, had an impact upon the results, but it would be helpful to prove this.

\section{Conclusion}

This study has attempted to show how a situated methods-comparison study can inform us about the relative effectiveness of two types of communicative teaching, TPR and PPP, when teaching spoken language to beginner level young learners. The results show that while both were effective, PPP was marginally more effective in developing receptive knowledge in the short term. We suggest that the results could be developed as part of action research and through more extensive research projects.

\section{References}

Asher, J. J. (1969). The total physical response approach to second language learning. The Modern Language Journal, 53(1), 3-17.

Asher, J. J. (2009). The total physical response (TPR): Review of the evidence. Retrieved from < http://www.tpr-world. com/review_evidence.pdf >

Byrne, D. (1986). Teaching oral English. Harlow: Longman.

Cook, G. (2010). Translation in language teaching. Oxford: Oxford University Press.

Cohen, J. (1988). Statistical power analysis for the behavioral sciences. New Jersey: Lawrence Erlbaum Associates.

Field, A. (2013). Discovering statistics using IBM SPSS statistics (4th ed.). London: Sage.

Glasgow, G. P. (2012). Implementing language education policy to "conduct classes in English" in Japanese senior high schools. In N. Sonda \& A. Stewart (Eds.), JALT 2011 Conference Proceedings (pp. 399-407). Tokyo: JALT.

Lewis, M. (1993). The lexical approach. Hove: Language Teaching Publications.

Ministry of Education, Culture, Sports, Science and Technology. (2008). Improvement of Academic Abilities: Lower Secondary School, Section 9: Foreign Languages. Retrieved from <http://www.mext.go.jp/component/english/__icsFiles/afieldfile/2011/03/17/1303755_013.pdf>

Muranoi, H. (2007). Output practice in the L2 classroom. In R. M. DeKeyser (Ed.), Practice in a second language. Perspectives from applied linguistics and cognitive psychology (pp. 51-84). Cambridge: Cambridge University Press.

Norris, J. M., \& Ortega, L. (2000). Effectiveness of L2 instruction: A research synthesis and quantitative meta-analysis. Language Learning, 50(3), 417-528.

Norris, J. M., \& Ortega, L. (2001). Does type of instruction make a difference? Substantive findings from a meta-analytic review. In R. Ellis (Ed.), Form-focused instruction and second language learning (pp. 157-213). Oxford: Blackwell.

Richards, J. (2006). Communicative language teaching today. Cambridge: Cambridge University Press.

Sato, R. (2010). Reconsidering the effectiveness and suitability of PPP and TBLT in the Japanese EFL Classroom. JALT Journal, 32, 189-200.

Schmitt, N. (2010). Researching vocabulary: A vocabulary research manual. Basingstoke: Palgrave Macmillan.

Watanabe, K., \& Kawabuchi, K. (2008). Long-term retention of English through TPR in a Japanese high school. Bulletin of Center for Educational Research and Development, 17, 53-58. Nara University of Education Academic Repository. Retrieved from <http://dspace.nara-edu.ac.jp/bitstream/10105/671/1/CERD2008-R09.pdf> 
Yan-Ping, Z. (1991). The effect of explicit instruction on the acquisition of English grammatical structures by Chinese learners. In C. James, \& P. Garrett (Eds.), Language awareness in the classroom (pp. 254-277). Harlow: Longman.

Yoshimi, D. R. (2001). Explicit instruction and JFL learners' use of interactional discourse markers. In K. R. Rose \& G. Kasper (Eds.), Pragmatics in language teaching (pp. 223-244). Cambridge: Cambridge University Press.

Christian Jones is a Senior Lecturer in TESOL at the University of Central Lancashire, UK and has previously worked as a teacher and teacher trainer in Japan and Thailand. His main research interests are in spoken language, corpus-informed language teaching and lexis, and the pedagogical treatment of spoken grammar.

Email: <cjones3@uclan.ac.uk>

Michelle Lees is a third year Assistant Language Teacher on the JET Programme in Oita, Japan. Her research areas of interest include motivation and socio-cultural factors that affect SLA, English language education in Japan, and English as an international language.

Email: <leesmicheller@gmail.com>

Natalie Donohue is now an English instructor at Bilkent University in Turkey, after working for two years as a Senior High School ALT in Fukushima Prefecture on the JET Programme. Her research interests include accents, models of English, grammar teaching, and SLA.

Email: <nadonohue@gmail.com>

Karen Smith is a Lecturer in EAP/ study skills at University of Central Lancashire, UK and also a teacher trainer in EFL. She has extensive international teaching experience, including teaching young learners in Portugal and New Zealand. Her research interests include teaching practices, young learners, and developing literacy.

Email: <kfsmith@uclan.ac.uk>

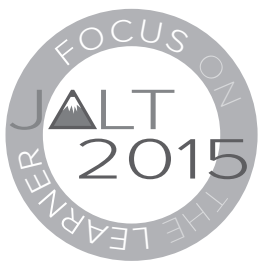

Nov. 20-23, 2015

Shizuoka Convention \& Arts

Center "GRANSHIP",

Shizuoka City, JAPAN

${ }^{*}$ Call for Presentations open

until Feb 15, 2015

\section{Appendices}

Appendix A: Sample productive test, and Appendix B: Lesson procedures are also available in the online version of this article at <http://jalt-publications.org/tlt>.

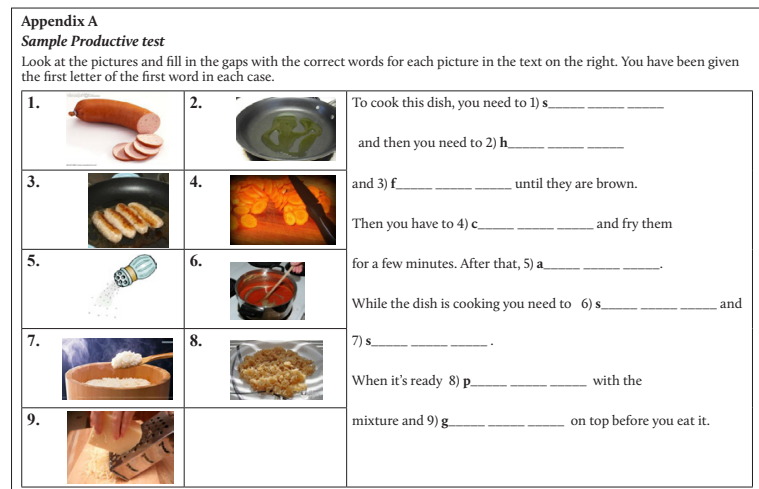

Sample Receptive test

Match the words on the left $(1-4)$ with the words on the right $(A-D)$ so that they describe what is happening in the pictures

\begin{tabular}{|l|l|l|}
\hline 1. steam & A. the carrots & \\
\hline 2. chop & B. the mixture & \\
\hline 3. grate & C. the cheese & \\
\hline 4. stir & D. the rice & \\
\hline
\end{tabular}

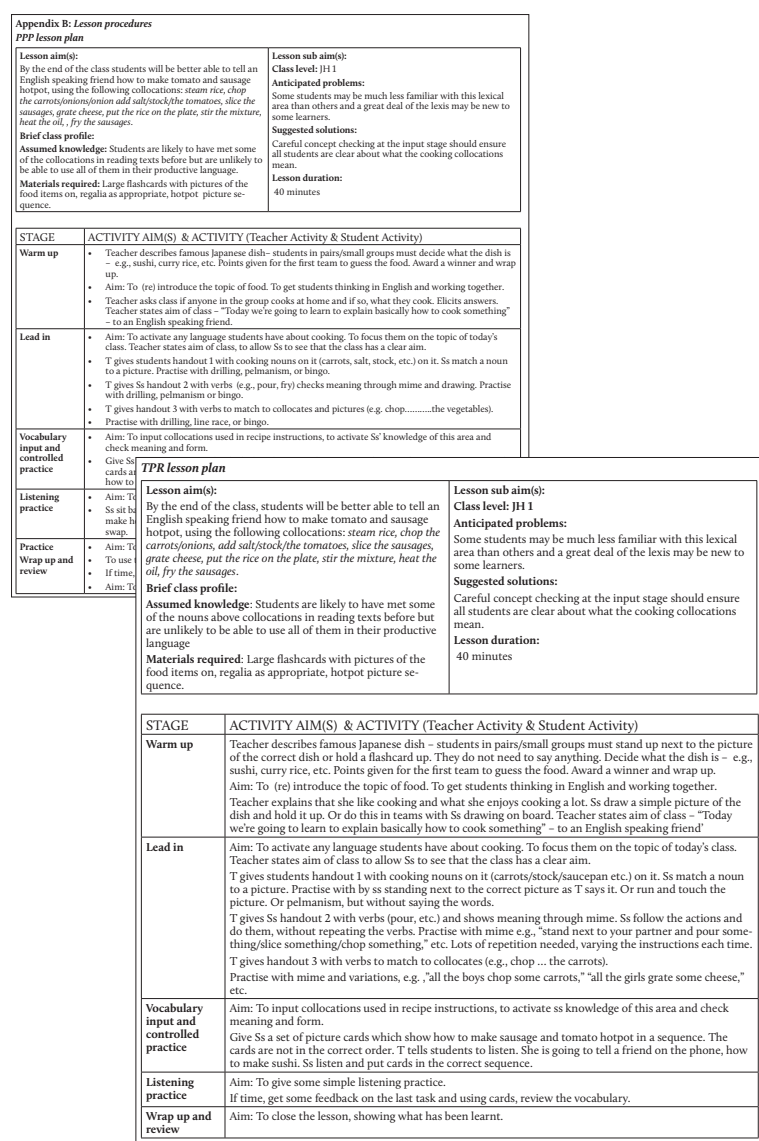




\section{Appendix A}

\section{Sample Productive test}

Look at the pictures and fill in the gaps with the correct words for each picture in the text on the right. You have been given the first letter of the first word in each case.

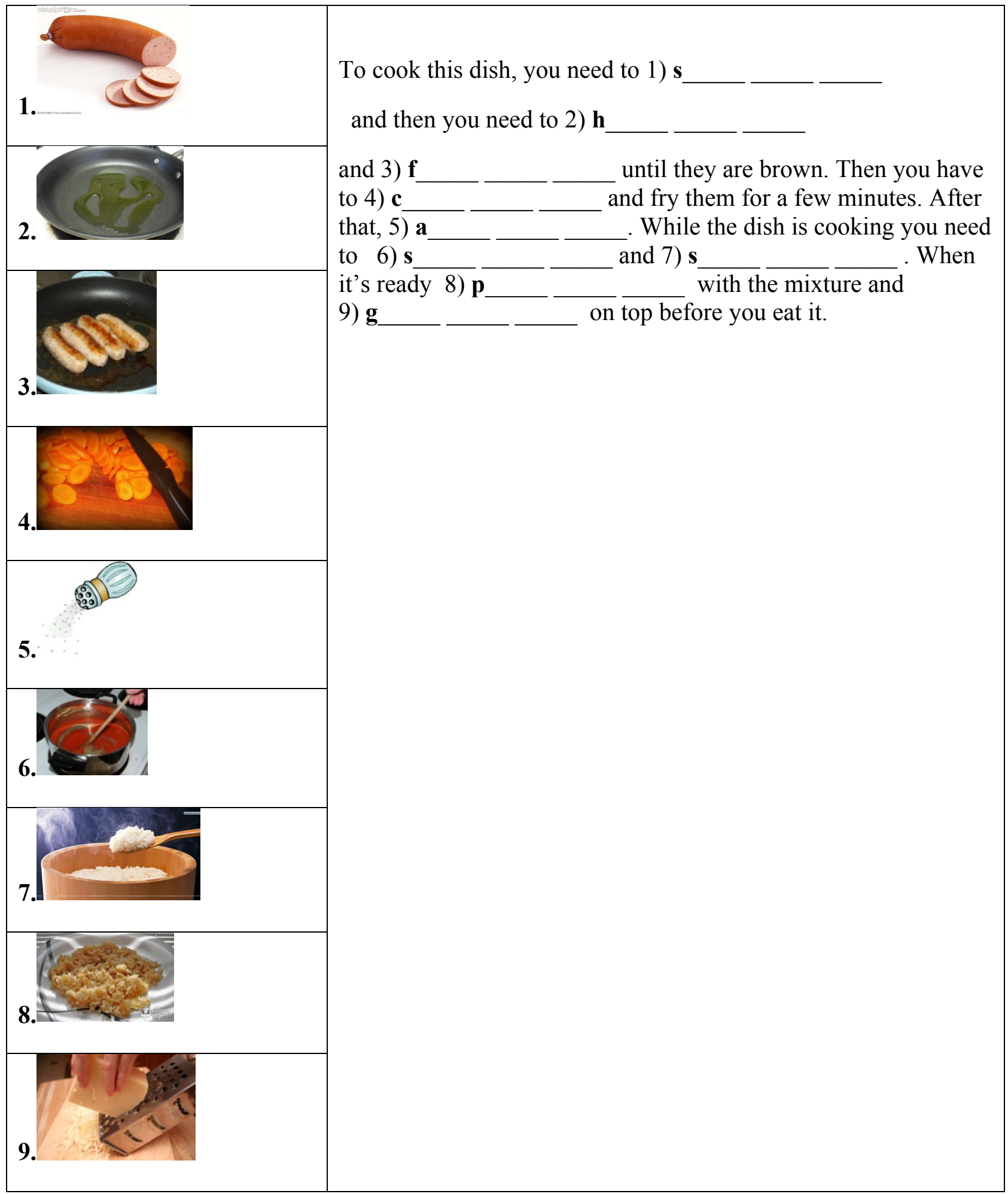


Sample Receptive test

Match the words on the left $(1-4)$ with the words on the right $(A-D)$ so that they describe what is happening in the pictures on the right. Write the answer next to the picture, e.g., 1B or $2 \mathrm{C}$.

\begin{tabular}{|l|l|l|}
\hline 1. steam & A. the carrots & B. the mixture \\
\hline 2. chop & C. the cheese & \\
\hline 3. grate & D. the rice & \\
\hline 4. stir & & \\
\hline
\end{tabular}

\section{Appendix B}

Lesson procedures

PPP lesson plan

\section{Lesson $\operatorname{aim}(\mathbf{s})$ :}

By the end of the class students will be better able to tell an English speaking friend how to make tomato and sausage hotpot, using the following collocations: steam rice, chop the carrots/onions/onion add salt/stock/the tomatoes, slice the sausages, grate cheese, put the rice on the plate, stir the mixture, heat the oil, , fry the sausages.

\section{Brief class profile:}

Assumed knowledge: Students are likely to have met some of the collocations in reading texts before but are unlikely to be able to use all of them in their productive language.

Materials required: Large flashcards with pictures of the food items on, regalia as appropriate, hotpot picture sequence.

\section{Lesson sub aim(s):}

Class level: JH 1

Anticipated problems:

Some students may be much less familiar with this lexical area than others and a great deal of the lexis may be new to some learners.

\section{Suggested solutions:}

Careful concept checking at the input stage should ensure all students are clear about what the cooking collocations mean.

\section{Lesson duration:}

40 minutes 


\begin{tabular}{|c|c|}
\hline STAGE & $\begin{array}{c}\text { ACTIVITY AIM(S) \& ACTIVITY (Teacher Activity \& Student } \\
\text { Activity) }\end{array}$ \\
\hline Warm up & $\begin{array}{l}\text { Teacher describes famous Japanese dish-students in pairs/small groups } \\
\text { must decide what the dish is - e.g., sushi, curry rice, etc. Points given for } \\
\text { the first team to guess the food. Award a winner and wrap up. } \\
\text { Aim: To (re) introduce the topic of food. To get students thinking in } \\
\text { English and working together. } \\
\text { Teacher asks class if anyone in the group cooks at home and if so, what } \\
\text { they cook. Elicits answers. Teacher states aim of class - "Today we're } \\
\text { going to learn to explain basically how to cook something" - to an English } \\
\text { speaking friend. } \\
\text { Aim: To activate any language students have about cooking. To focus } \\
\text { them on the topic of today's class. Teacher states aim of class, to allow Ss } \\
\text { to see that the class has a clear aim. } \\
\text { T gives students handout } 1 \text { with cooking nouns on it (carrots, salt, stock, } \\
\text { etc.) on it. Ss match a noun to a picture. Practise with drilling, pelmanism, } \\
\text { or bingo. } \\
\text { T gives Ss handout } 2 \text { with verbs (e.g., pour, fry) checks meaning through } \\
\text { mime and drawing. Practise with drilling, pelmanism or bingo. } \\
\text { T gives handout } 3 \text { with verbs to match to collocates and pictures (e.g. } \\
\text { chop..........the vegetables). } \\
\text { Practise with drilling, line race, or bingo. }\end{array}$ \\
\hline $\begin{array}{l}\text { Vocabulary } \\
\text { input and } \\
\text { controlled } \\
\text { practice }\end{array}$ & $\begin{array}{l}\text { Give Ss a set of picture cards which show how to make sausage and } \\
\text { tomato hotpot in a sequence. The cards are not in the correct order. T tells } \\
\text { students to listen. She is going to tell a friend on the phone how to make } \\
\text { tomato hotpot. Ss listen and put cards in the correct sequence. } \\
\text { Aim: To give Ss a clear model of the final task and some simple listening } \\
\text { practice. } \\
\text { Ss sit back to back. One is an English-speaking friend. The other is } \\
\text { phoning them to tell them how to make hotpot. The "friend' must ask one }\end{array}$ \\
\hline
\end{tabular}




\begin{tabular}{|l|l|}
\hline $\begin{array}{l}\text { Listening } \\
\text { practice }\end{array}$ & $\begin{array}{l}\text { or two questions. Tell each other (using pics to help) and then swap. } \\
\text { Aim: To use the language input from the lesson in a clear and possible } \\
\text { context } \\
\text { To use the language input from the lesson in a clear and possible context. } \\
\text { If time, get some feedback on the last task and using cards, review the } \\
\text { vocabulary. } \\
\text { Aim: To close the lesson, showing what has been learnt. }\end{array}$ \\
\hline $\begin{array}{l}\text { Practice } \\
\text { Wrap up and }\end{array}$
\end{tabular}

TPR lesson plan

Lesson $\operatorname{aim}(\mathrm{s})$ :

By the end of the class, students will be better able to tell an English speaking friend how to make tomato and sausage hotpot, using the following collocations: steam rice, chop the carrots/onions, add salt/stock/the tomatoes, slice the sausages, grate cheese, put the rice on the plate, stir the mixture, heat the oil, fry the sausages.

Brief class profile:

Assumed knowledge: Students are likely to have met some of the nouns above collocations in reading texts before but are unlikely to be able to use all of them in their productive language

Materials required: Large flashcards with pictures of the food items on, regalia as
Lesson sub aim(s):

Class level: JH 1

Anticipated problems:

Some students may be much less familiar with this lexical area than others and a great deal of the lexis may be new to some learners.

Suggested solutions:

Careful concept checking at the input stage should ensure all students are clear about what the cooking collocations mean.

Lesson duration:

40 minutes 
appropriate, hotpot picture sequence.

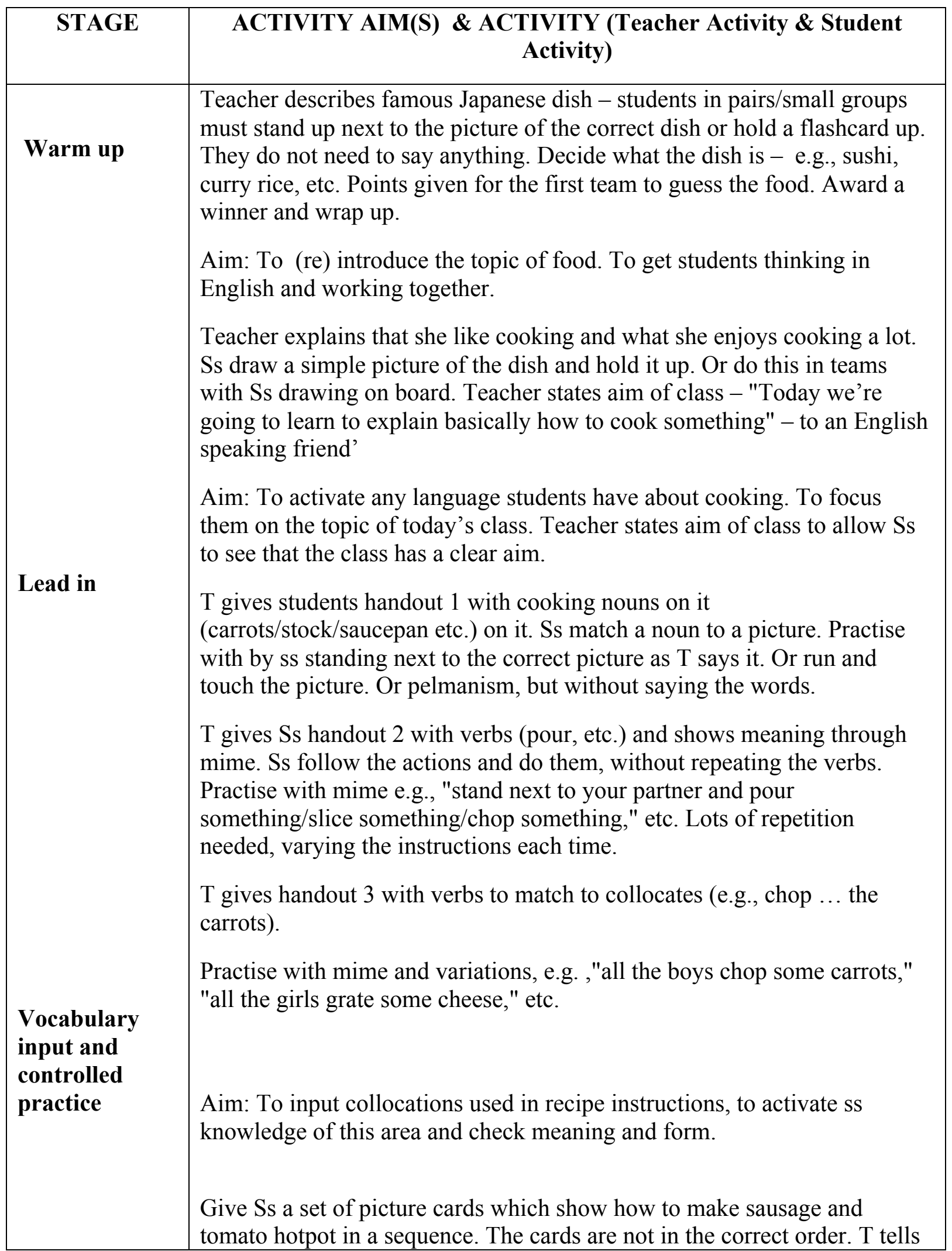




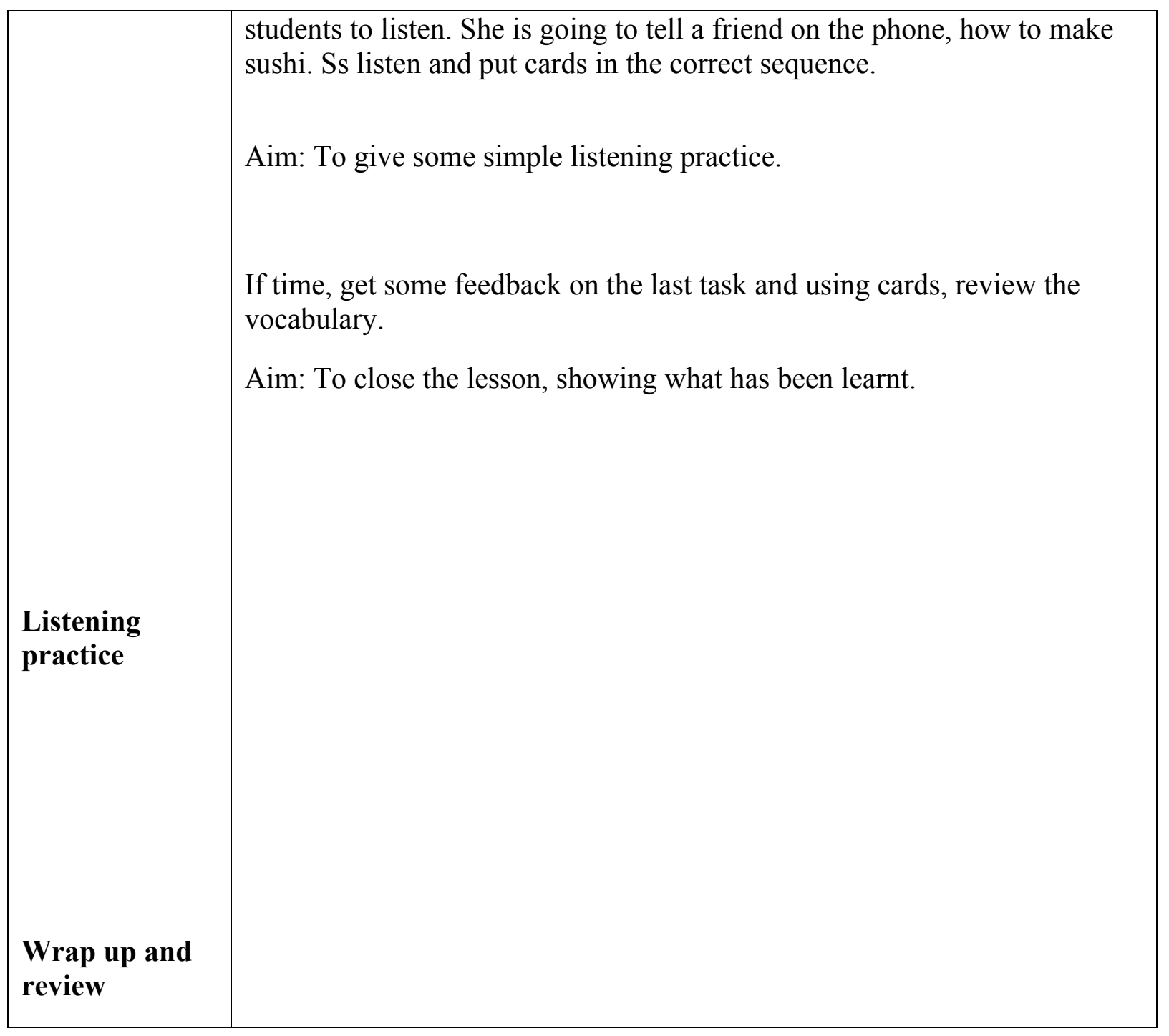

